International Journal of Business Management and Economic Review

Vol. 2, No. 06; 2019

ISSN: 2581-4664

\title{
THE ROLE OF ORGANIZATIONAL CULTURE AND EMPLOYEE PERFORMANCE AS FACTORS THAT AFFECTING WORK ENGAGEMENT: STUDY IN INDONESIAN BROADCASTING COMMISSION IN ACEH
}

\author{
Awwaliah, Abdul Rahman Lubis and Djuraidin Ismail \\ Department of Management, Universitas Syiah Kuala, Indonesia \\ http://doi.org/10.35409/IJBMER.2019.2431
}

\begin{abstract}
The purpose of this study is to verify the effect of organizational culture on employee performance, the effect of organizational culture on work engagement, and the effect of employee performance on work engagement. The object is the Indonesian Broadcasting Commission (KPI) Aceh. The population in this study is 130 people, while the sampling technique uses census technique, because it involves the entire population as respondents, so the number of respondents is also as much as 130 people. Data is analyzed using Structural Equation Modelling (SEM), that is helped by AMOS software. The result shows that organizational culture effects employee performance significantly, organizational culture affects work engagement significantly, and employee performance effects work engagement significantly. These all findings are in line with the previous theories, and can be the updates of the casuality theories to enrich the realm of science. For academician, this will be a reference for futher research, to develop their model model. For the practical persons escpeciall for employees in KPI Aceh they need to consider the variables related to improve their performance.
\end{abstract}

Keyword: Organizational Culture, Employee Performance, Work Engagement.

\section{INTRODUCTION}

In order to carry out its functions, KPI has the authority to prepare and supervise various broadcasting regulations that connect between broadcasting institutions, the government and the public. This arrangement covers all the processes of the broadcasting activity cycle, starting from the stage of establishment, operationalization, accountability and evaluation. In doing all of this, KPI coordinates with the government and other state institutions, because the spectrum of the regulation of the Broadcasting Law is categorized as a criminal offense. In addition, the KPI also deals with the community in accommodating and following up on all forms of public appreciation towards broadcasting institutions as well as the broadcasting world in general. In this research, KPI Aceh refers to a branch of the KPI institution that located in Aceh province, Indonesia.

In order to carry out the authority possessed by the KPI and also carry out duties and obligations, human resources with high integrity and loyalty are needed and have ideas or ideas 


\section{International Journal of Business Management and Economic Review}

Vol. 2, No. 06; 2019

ISSN: 2581-4664

that are useful for the existence of KPI as a means of controlling broadcasting in the community, therefore necessary employees who have a higher attachment to their organization (work engagement).

Work engagement has become the most discussed important topic in recent years among well-known consulting and media business companies and non-profit organizations (Saks, 2006). The research result of (Abdurrauf, Lubis, \& Chan, 2015), says an organizational culture that is built into the organizational environment will provide an influence in improving employee performance.

In various academic references, it is mentioned that engagement has a relationship with the mind (Saks, 2006). The mind in organizational behavior is the same as talking about employee relations with organizations. As one of the thoughts in organizational behavior, work attachments are different from other thoughts such as commitment to the organization.

When an employee is tied to a company, the employee has an awareness of the goals desired by the organization. Awareness of the goals of an organization will make employees able to provide the capabilities they have to their organizations. Research shows that bonded employees are more productive employees (Consulting, 2004). Employees who provide good capabilities will have an impact on the company performance. (Saks, 2006) states that many claims that work attachment predicts employee impact, organizational success and employee performance (such as: improving service quality).

While the research conducted by (Sulaiman \& Basyir, 2017) state that the performance produced by an employee can influence employee work engagement. In relation to work engagement, employees at the KPI Aceh are required to improve their capabilities and devote all their attention and ability to the progress of the KPI Aceh organization, especially in improving employee performance. Employee performance on the KPI Aceh is the result of work both in quality and in all employees of the KPI Aceh in accordance with their respective duties and functions such as conducting research and guiding and overseeing the illegal broadcast spectrum.

The situation that has occurred so far is the declining performance of the KPI Aceh, especially in achieving certain predetermined work targets, especially in dealing with various issues related to complaints s from the public regarding several television and radio broadcasts that are not in accordance with the norms and culture of the Acehnese community. This phenomenon is at least seen from the unfulfilled expectations of the leadership of the work results of employees in the KPI Aceh, both in terms of quantity and quality.

Employee performance on the KPI Aceh can in fact not be measured materially or nonfinancially, but can be seen in the completion of the timeliness work, the quality of services provided as determined by the respective leaders. Improving employee performance cannot be separated from the existence of organizational culture within the organization. The organizational culture that applies in the KPI Aceh is a tangible manifestation of the actualization of organizational culture which is a comprehensive program in accelerating efforts to renew the organization's operational activities more efficiently and effectively. This finding is reinforced by the results of research conducted by (Rizwan, Musnadi, \& Faisal, 2018) which states that organizational culture in a government organization in this case Meuraxa public hospital has an influence in improving the performance of employees in the hospital.

The phenomenon related to the ideal organizational culture for employees at the KPI Aceh is an organizational structure that is in accordance with the capabilities of the employees. 


\section{International Journal of Business Management and Economic Review}

Vol. 2, No. 06; 2019

ISSN: 2581-4664

The specified work standards must also be in accordance with the capabilities of employees, employee responsibilities for the main tasks and functions, giving awards to employees who have work performance so that it can affect organizational performance. But in fact the organizational structure of the KPI Aceh is not yet in accordance with the capabilities possessed by the employees, the work standards set are also relatively high so that the main tasks and functions are not going well, rarely does the leader reward employees who excel.

The phenomenon that occurred in the KPI Aceh, there are still many KPI employees who still neglect their duties and functions, so that the resulting performance is not achieved in accordance with the targeted performance. This can be seen from the quantity of work that can be produced by employees, then the quality of work that can be received by the leaders is also still of poor quality, the knowledge factor possessed by employees is also one of the obstacles in achieving the expected performance of the leadership, and coordination employees between fields have not run well, so that performance achievements cannot be realized properly. In addition, the low performance of employees can also be seen from the low initiative of employees to find the right method or method in order to improve performance.

\section{LITERATURE REVIEW Organizational Culture}

Organizational culture comes from two words, namely culture and organization. Regarding culture, (Kottler \& Heskett, 2007) formally defines culture as the totality of patterns of behavior, art, trust, institutions and all other products of human work and thought that distinguish a society. For (Pajares, 1996), culture is a shared value created by a group of people at a certain time.

Various cultural attributes have been arranged based on norms and attitudes that help distinguish one company from another. (Forehand \& Von Haller, 1964) The process of thinking helps in building one member from another on the basis of cognitive thinking (Hofstede, 2011). Guidelines for success are based on different values and norms that make culture effective (Schein, 1996). A set of beliefs, behaviors, norms and values help in making the culture most effective (Kottler \& Heskett, 2007). Knowledge about culture has been gained through understanding and confidence on the basis of large groups.

\section{Employee Performance}

The level of achievement where employees fulfill the organization's mission in the workplace is called performance (Cascio, 2006). Performance has been felt differently by various researchers, but most scholars relate to performance with measurements of transactional effectiveness and effectiveness of organizational goals (Stannack, 1996).

An employee's work is built on the level of achievement of certain targets or missions that determine performance limits (Cascio, 2006). Certain researchers have identified different thinking, attitudes and performance beliefs because they help in measuring input and output efficiency measures that lead to transactional associations. (Stannack, 1996) The organization's ability to establish perfect relationships with resources presents effective and efficient resource management. (Daft \& Marcic, 2008) To achieve the goals and objectives of the organization's strategy has been designed based on organizational performance. (Wade \& Recardo, 2001) says equity based on high return helps in effective organizational resource management so the 


\section{International Journal of Business Management and Economic Review}

Vol. 2, No. 06; 2019

ISSN: 2581-4664

performance increases.

Culture is defined as a mixture of values, sets, beliefs, communication and behavioral explanations that provide guidance to people. The main idea of culture comes from sharing in the learning process which is based on systematic allocation of resources. (Titiev, 1959) The human cognitive system that helps in improving thinking and decision making is based on organizational culture. (Pettigrew, 1979) A diverse collection of beliefs, assumptions, and values helps in presenting different cultural levels by doing business in an effective way. Normative glue based on organizational culture helps in maintaining overall management effectiveness. (Tichy, 1982). The concept of effective organizational culture helps in improving business decisions. Cultural survival in an organization lies in the differentiation of national and foreign cultures in cultural management (Schein, 1996) describes Organizational culture has been influenced by attitudes, norms and beliefs that lead to strong communication between employees.

\section{Work engagement}

Performance measurement systems help in increasing organizational associations to achieve goals and objectives in an effective way. (Ittner \& Larcker, 1998) Strategic planning based on developing goals and objectives helps the organization to focus on non-financial or intangible assets. Quality, performance and services related to customers have financial properties (Kaplan \& Norton, 2001). The system of managing financial and non-financial benefits is possible by measuring and evaluating performance measurement systems.

Traditional performance measurement based on strategic performance systems. Translation and measurement of financial and non-financial performance based on SPMS leads to competitiveness (Chenhall, 2005). Measurement techniques help in increasing competitive advantage in organizations based on effective pressure. Various performance measures adopted by organizations based on non-financial and financial measures help in presenting uncontrolled events (Bruns, W. J. \& McKinnon, 1993). The measurement techniques adopted by the organization help in presenting positive relationships of goods and services.

Work engagement is a concept that is developed from the positive will of the psychological and positive organizational culture. (Ahmed, Khan, Khan, Tanveer, \& Lone, 2010) explains the opinion about the existence of a relationship and involvement that might occur between physically, cognitively and emotionally himself with someone with his role in a job, which is then referred to as an employee who is bound to his job. (Risher, 2010) states that an organization's commitment to one's success will often be referred to as work engagement. This is explained by research research that states as an emotional relationship of an employee with what is felt in the organization that affects it to get an independent and greater business for its responsibilities.

\section{Research Hypothesis}

Based on the problems and literatires above, the hypothesis that can be formulated from this research model as follows.

H1 : organizational culture effects employee performance significantly;

$\mathrm{H} 2$ : organizational culture affects work engagement significantly, and;

$\mathrm{H} 3$ : employee performance effects work engagement significantly.

\section{RESEARCH METHOD}




\section{International Journal of Business Management and Economic Review}

Vol. 2, No. 06; 2019

ISSN: 2581-4664

This research was conducted on the KPI Aceh which is a government-owned broadcasting institution as the authority that will arrange and control various broadcast rules with broadcasting institutions, others outside the government and the community. This regulation covers all recycling of broadcasting and activity processes, starting from the establishment, operational, accountability and evaluation stages, while the object of this research is the influence of an organization's culture on employee performance and its implications for engagement of KPI Aceh employees.

For sampling in the study carried out by census techniques for all employees on the KPI Aceh, in this study there are 130 respondents. The sample to be chosen is all employees who can answer all questions that have a relationship with the influence of organizational culture, employee performance and work engagement. After collecting data, then the authors analyze this data by using Structural Equation Model (SEM) with AMOS software. SEM can be described as an analysis that approaches factor analysis, structure model, and route analysis.

\section{RESULT}

The analysis of the SEM is carried out in a full model, then the analysis of the unitary stage in the nationality of the pointer that forms the latent change is tested by the validation factor analysis. The result of processing data analysis at the full stage of the SEM model is carried out by conducting suitability tests and statistical tests. The processing decision for the full analysis of the SEM model is shown in the following figure:

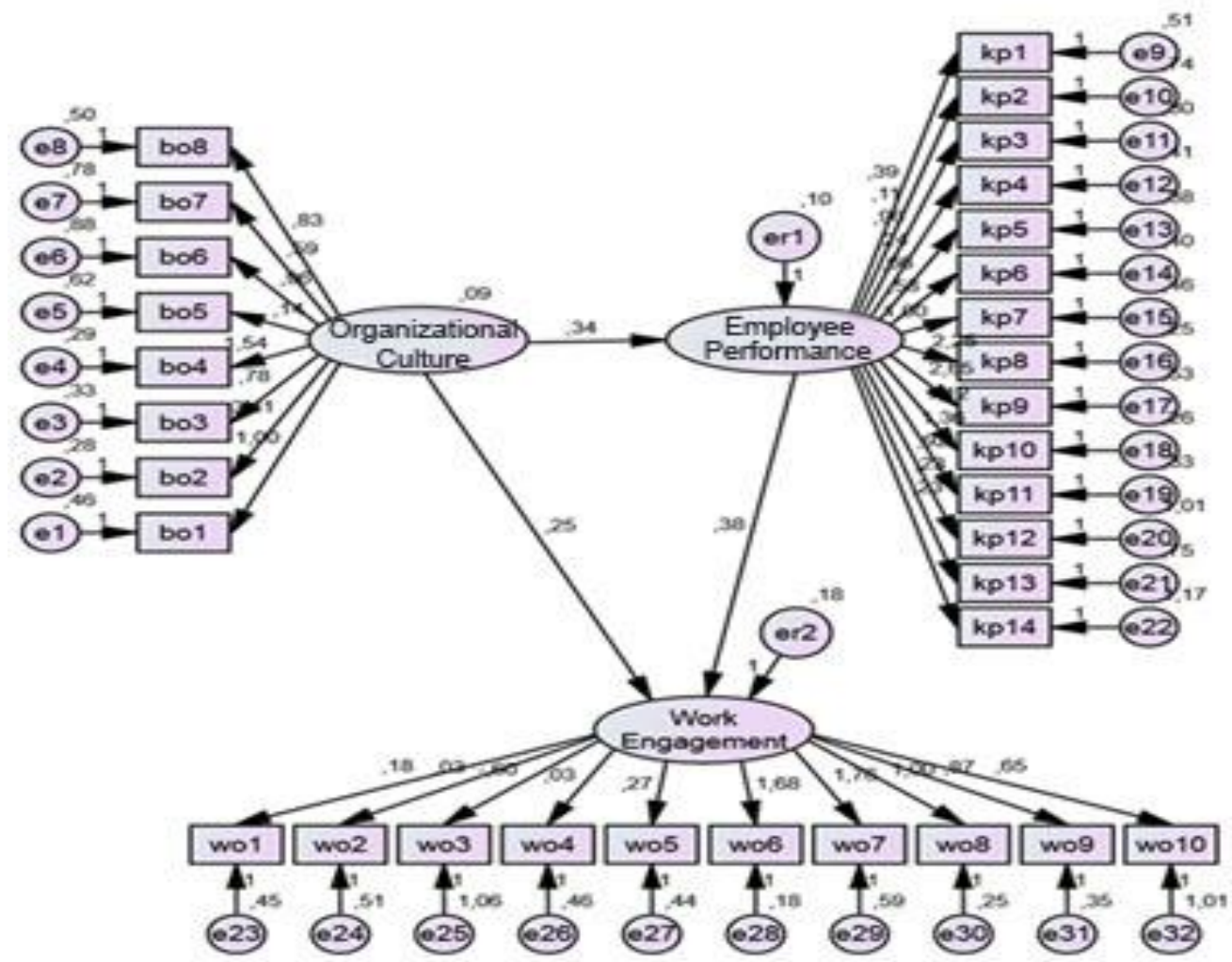

Figure 1. Structural Equation Model (SEM) 


\section{International Journal of Business Management and Economic Review}

Vol. 2, No. 06; 2019

ISSN: 2581-4664

\section{H1 is accepted : The effect of Organizational Culture on Employee Performance}

The effect of organizational cultural on employee performance shows the CR value 2.221 and with a probability 0.000 . Thus it can be concluded that the organizational culture of the KPI Aceh has an effect on improving employee performance. This result is consistent with the research conducted by Suparjo, et al (2015) that also shows thet organizational culture has an influence on improving employee performance

\section{H2 is accepted : The Effect of Organizational Culture on Work Engagement}

The effect of organizational culture on work engagement shows a CR value 2.102 and a probability of 0.000 . Thus it can be concluded that the organizational culture of the KPI Aceh has an effect on improving work engagement work. This indicates that the better organizational culture will improve employee work engagement.

\section{H3 is accepted : The Effect of Employee Performance on Work Engagement}

The effect of employee performance against employee work engagement shows a CR value of 3.663 and with sig of 0,000 or less than $5 \%$. Therefore, it can be concluded that the employee performance produced can have an influence on improving work engagement of employees in the KPI Aceh.

\section{CONCLUSIONS}

The result shows that organizational culture effects employee performance significantly, organizational culture affects work engagement significantly, and employee performance effects work engagement significantly. These all findings are in line with the previous theories, and can be the updates of the casuality theories to enrich the realm of science. For academician, this will be a reference for futher research, to develop their model model. For the practical persons escpeciall for employees in KPI Aceh they need to consider the variables related to improve their performace.

Based on the cultural perspective of the organization, it is necessary to get attention from the leaders that employees need to be given the freedom in issuing opinions in the meeting forums at the office. Then the employee performance problem that must be improved is the skills possessed by the employee must be in accordance with the work done by the employee. Others, to improve work engagement, what needs to be considered is that an employee must know what is expected of a job. And finally, the KPI Aceh must be able to find or seek concrete efforts to fix the organization.

\section{REFERENCES}

Abdurrauf, Lubis, A. rahman, \& Chan, S. (2015). Pengaruh Produktivitas Kerja Dan Penegakan Disiplin Terhadap Kinerja Pegawai Serta Dampaknya Terhadap Kinerja Sekretariat Daerah Aceh. Jurnal Management, 4(1), 211-220.

Ahmed, Z., Khan, S. S., Khan, M., Tanveer, A., \& Lone, Z. A. (2010). Synergistic Effect of 


\section{International Journal of Business Management and Economic Review}

Vol. 2, No. 06; 2019

ISSN: 2581-4664

Salvadora persica Extracts, Tetracycline and Penicillin Against Staphylococcus aureus. African Journal of Basic \& Applied Sciences, 2(12), 25-29.

Bruns, W. J., J., \& McKinnon, S. M. (1993). Information and Managers: A Field Study. Journal of Management Accounting Research, 5, 84-108.

Cascio, W. (2006). Managing Human Resources: Productivity, Quality of Work Life, Profits (7th, illustr ed.). New York: McGraw-Hill.

Chenhall, R. H. (2005). Integrative strategic performance measurement systems, strategic alignment of manufacturing, learning and strategic outcomes: An exploratory study. Accounting, Organizations and Society, 30(5), 395-422. https://doi.org/10.1016/j.aos.2004.08.001

Consulting, G. (2004). Study Engaged Employees Inspire Company Innovation.

Daft, R. L., \& Marcic, D. (2008). Understanding management (10th ed.). Kentucky: South Western Educational Publishing.

Forehand, G. A., \& Von Haller, G. (1964). No Title. Psychological Bulletin, 62(6), 361-382. https://doi.org/http://dx.doi.org/10.1037/h0045960

Hofstede, G. (2011). Dimensionalizing Cultures: The Hofstede Model in Context Dimensionalizing Cultures: The Hofstede Model in Context. Online Readings in Psychology and Culture, 2(1), 1-26. https://doi.org/https://doi.org/10.9707/2307-0919.1014

Ittner, C. D., \& Larcker, D. F. (1998). Are Nonfinancial Measures Leading Indicators of Financial Performance? An Analysis of Customer Satisfaction. Journal of Accounting Research, 36, 1-36. https://doi.org/10.2307/2491305

Kaplan, R. S., \& Norton, D. P. (2001). Transforming the Balanced Scorecard from Performance Measurement to Strategic Management: Part II. Accounting Horizons, 15(2), 147-160.

Kottler, \& Heskett. (2007). The Work engagement Equation in India. Presented by Blessing White and HR Anexi.

Pajares, F. (1996). Self-Efficacy Beliefs in Academic Settings. Review of Educational Research, 66(4), 543-578. https://doi.org/10.3102/00346543066004543

Pettigrew, T. F. (1979). The Ultimate Attribution Error: Extending Allport's Cognitive Analysis of Prejudice. Personality and Social Psychology Bulletin, 5(4), 461-476. https://doi.org/10.1177/014616727900500407

Risher, H. (2010). Don't Overlook Frontline Supervisors. The Public Manager, 39(3), 74-76.

Rizwan, Musnadi, S., \& Faisal. (2018). PENGARUH BUDAYA ORGANISASI DAN 


\section{International Journal of Business Management and Economic Review}

Vol. 2, No. 06; 2019

ISSN: 2581-4664

KETERLIBATAN KERJA TERHADAP KOMITMEN ORGANISASI SERTA IMPLIKASINYA PADA KINERJA KARYAWAN RSUD MEURAXA KOTA BANDA ACEH. Jurnal Magister Manajemen, 2(1), 78-87. Retrieved from http://jurnal.unsyiah.ac.id/JMM

Saks, A. M. (2006). Employee engagement: Antecendents and consequences. Journal of Managerial Psychology, 21(7), 600-619.

Schein, E. H. (1996). Three cultures of management: The key to organizational learning. Sloan Management Review, 38(1), 9-20.

Stannack, P. (1996). Perspectives on Employee Performance. Management Research News, 19(4), 38-40. https://doi.org/https://doi.org/10.1108/eb028456

Sulaiman, \& Basyir, M. (2017). Customer Relationship Management, Customer Satisfaction And Its Impact On Customer Loyalty. Internationalization of Small Medium Enterprises (SMEs): Challenges and Prospects, The 1st International Conference on Community Research and Service Engagements. https://doi.org/978-602-501-311--9

Tichy, N. M. (1982). Managing change strategically: the technical, political, and cultural keys. Organizational Dynamics, 11(2), 59-80. https://doi.org/https://doi.org/10.1016/00902616(82)90005-5

Titiev, M. (1959). Introduction to Cultural Anthropology. Retrieved from https://books.google.co.id/books?id=BqtnAAAAIAAJ

Wade, D., \& Recardo, R. (2001). Corporate Performance Management: How to build a better organization through measurement-driven, strategic alignment (Improving Human Performance) (1 edition). New York: taylor \& francis. 